\title{
Direct suppression of Pth gene expression by the vitamin D prohormones doxercalciferol and calcidiol requires the vitamin $\mathrm{D}$ receptor
}

\author{
Cynthia S Ritter and Alex J Brown \\ Renal Division, Washington University School of Medicine, PO Box 8126, 660 South Euclid, St Louis, Missouri 63110, USA \\ (Correspondence should be addressed to A J Brown; Email: abrown@dom.wustl.edu)
}

\begin{abstract}
Vitamin D compounds regulate PTH at the transcriptional level, presumably via binding to the vitamin D receptor (VDR), but the exact mechanism is presently unclear. We recently reported that the several vitamin $\mathrm{D}$ prohormones with low VDR affinity suppressed PTH, even when their activation was inhibited, raising the possibility that their actions may be VDR independent. To test this hypothesis, we developed a novel organ culture that allowed the assessment of activities of the prohormones on PTH release from wild-type and VDR-null thyroparathyroid explants. The cultures remained viable with respect to PTH release for at least 2 weeks. Full suppression of PTH by the native vitamin D hormone, 1 $\alpha, 25$-dihydroxyvitamin $\mathrm{D}_{3}\left[1 \alpha, 25(\mathrm{OH})_{2} \mathrm{D}_{3}\right]$, required 2 days, consistent with a transcriptional mechanism, and was reversible, indicating that reduced PTH was not attributable to cell death. Inhibition of PTH release by $1 \alpha, 25(\mathrm{OH})_{2} \mathrm{D}_{3}$ and two prohormones, 25-hydroxyvitamin $D_{3}$ and $1 \alpha$-hydroxyvitamin $D_{2}$, was observed in explants from wild-type mice but not in those from VDR-null mice. These findings 1) are the first direct demonstration of the role of the VDR in regulation of PTH by $\left.1 \alpha, 25(\mathrm{OH})_{2} \mathrm{D}_{3}, 2\right)$ confirm that the suppressive actions of the vitamin $\mathrm{D}$ prohormones are mediated by the VDR, and 3 ) introduce a novel organ culture model that allows the ex vivo study of the function of parathyroid glands from transgenic animals.
\end{abstract}

Journal of Molecular Endocrinology (2011) 46, 63-66

\section{Introduction}

The parathyroid glands play a central role in calcium homeostasis. A drop in serum calcium triggers the release of PTH, which enhances renal calcium reabsorption and bone calcium mobilization. PTH also stimulates the renal synthesis and release of 1 $\alpha, 25$-dihydroxyvitamin $\mathrm{D}_{3}\left[1 \alpha, 25(\mathrm{OH})_{2} \mathrm{D}_{3}\right]$, which increases intestinal calcium absorption. Restoration of calcium levels reduces PTH release by inhibiting exocytosis, promoting PTH peptide degradation, and destabilizing Pth mRNA. PTH is also suppressed via a feedback loop in which $1 \alpha, 25(\mathrm{OH})_{2} \mathrm{D}_{3}$ blocks $P$ th gene transcription.

The mechanism for transrepression of the Pth gene by $1 \alpha, 25(\mathrm{OH})_{2} \mathrm{D}_{3}$ remains controversial. At least three distinct mechanisms have been proposed, but none have been tested directly in parathyroid cells. The first model proposes that $1 \alpha, 25(\mathrm{OH})_{2} \mathrm{D}_{3}$-bound vitamin $\mathrm{D}$ receptor (VDR) binds to a negative vitamin $\mathrm{D}$ response element (VDRE) in the human PTH promoter, although the binding partner, if present, is not retinoid $\mathrm{X}$ receptor as is often seen with positive VDREs (Mackey et al. 1996). The second model proposes a more classical mechanism involving liganded VDR and RXR binding to a DR3-type element (two direct repeats of consensus 3-base elements separated by a 3-base spacer); this element is found in the rat and chick PTH promoters and was shown to act as a negative element in some, but not all, cell types, but has not been tested in parathyroid cells (Koszewski et al. 1999). More recently, a third model was proposed in which liganded VDR binds to and inactivates a positive effector (vitamin D interacting receptor or VDIR) of $P T H$ gene transcription, with no binding of the VDR to DNA (Murayama et al. 2004). Furthermore, although all of the mechanisms assume that the repression by $1 \alpha, 25(\mathrm{OH})_{2} \mathrm{D}_{3}$ is mediated by the VDR, this has not been demonstrated directly in parathyroid cells with the native gene.

We recently reported direct suppression of PTH by several vitamin D prohormones (or prodrugs) which lack key hydroxyl groups necessary for high affinity VDR binding (Brown et al. 2006, Ritter et al. 2006). The prodrugs $25(\mathrm{OH}) \mathrm{D}_{3}$ (calcidiol) and $1 \alpha(\mathrm{OH}) \mathrm{D}_{2}$ (doxercalciferol) retained full suppressive activity when their 'activation' by hydroxylases was blocked with cytochrome P450 inhibitors. The basis for the retention of PTH suppression is not clear, but several possibilities may be entertained. The prodrugs may accumulate in parathyroid cells to higher levels than $1 \alpha, 25(\mathrm{OH})_{2} \mathrm{D}_{3}$, which could overcome their lower VDR affinities. It is also possible that the protocols for measuring VDR affinities in vitro may 
not reflect the VDR affinities in the cells. At present, we cannot exclude the involvement of a unique receptor that mediates the direct actions of the prodrugs on Pth gene transcription. The existence of multiple receptors for vitamin D compounds was suggested by the studies of Panda et al. (2004), who found that the very high levels of $1 \alpha, 25(\mathrm{OH})_{2} \mathrm{D}_{3}$ in $V d r$ knockout mice suppressed parathyroid growth; the receptor involved has not been identified.

In the present study, we test the hypothesis that the direct suppression of PTH by $1 \alpha(\mathrm{OH}) \mathrm{D}_{2}$ and $25(\mathrm{OH}) \mathrm{D}_{3}$ is independent of the VDR. In vivo studies would not be informative since the prohormones would be activated. Therefore, we established a novel organ culture model utilizing thyroparathyroid explants from wild-type and $V d r$-null mice to determine the role of the receptor in the inhibition of $P$ th gene expression by $1 \alpha(\mathrm{OH}) \mathrm{D}_{2}$ and $25(\mathrm{OH}) \mathrm{D}_{3}$.

\section{Materials and methods}

\section{Animals}

A $V d r^{-/+}$breeding pair (B6.129S4-Vdr $r^{t m 1 M b d} / \mathrm{J}$ ) was purchased from Jackson Laboratory (Bar Harbor, ME, USA; contributed by Dr Marie Demay (Li et al. 1997)). Offspring were genotyped using the recommended primers CAC GAG ACT AGT GAG ACG TG (mutant), CTC CAT CCC CAT GTG TCT TT (wild-type), and TTC TTC AGT GGC CAG CTC TT (common) to yield bands of 500 and $382 \mathrm{bp}$ for the mutant and wild-type alleles, respectively. To prevent parathyroid hyperplasia, $V d r^{-/-}$mice were maintained on a diet containing $2.0 \% \mathrm{Ca}, 1.25 \% \mathrm{P}$, and $20 \%$ lactose (Teklad TD96348). All animal protocols were approved the Animal Studies Committee of Washington University School of Medicine.

\section{Organ culture}

Eight-week-old wild-type and $V d r$-null mice were killed under $\mathrm{CO}_{2}$. The trachea was teased away from surrounding tissue, and then severed anteriorly and posteriorly to the thyroid glands. This thyroparathyroid complex (TPTG), consisting of thyroid-parathyroidtracheal tissue, was excised and placed in $2 \mathrm{ml}$ serumfree medium (DME:Ham's F-12 (1:1, $1 \mathrm{mM} \mathrm{Ca}), 15 \mathrm{mM}$ HEPES, $100 \mathrm{IU} / \mathrm{ml}$ penicillin, $100 \mu \mathrm{g} / \mathrm{ml}$ streptomycin, $5 \mu \mathrm{g} / \mathrm{ml}$ insulin, $5 \mu \mathrm{g} / \mathrm{ml}$ holo-transferrin, $2 \mathrm{mM}$ glutamine, $1 \%$ nonessential amino acids, and $0.1 \%$ BSA) in a 24-well tissue culture plate. The medium was replaced daily and retained for analysis of PTH (Immutopics mouse intact PTH ELISA). The TPTG cultures were allowed to equilibrate for 3-6 days, with medium being replenished every 1-2 days. TPTGs were then washed one time and replenished with $2 \mathrm{ml}$ of fresh medium, which was collected after $24 \mathrm{~h}$ for a baseline PTH level. TPTGs were then treated with vehicle $(0 \cdot 1 \%$ ethanol $)$ or $100 \mathrm{nM} 1 \alpha, 25(\mathrm{OH})_{2} \mathrm{D}_{3}, 25(\mathrm{OH}) \mathrm{D}_{3}$, or $1 \alpha(\mathrm{OH}) \mathrm{D}_{2}$, and daily collections of medium were continued. In initial studies, $1 \alpha, 25(\mathrm{OH})_{2} \mathrm{D}_{3}$ was removed after 2 days of treatment to determine the reversibility of the suppression.

\section{Results}

\section{Characterization of cultured mouse TPTGs}

Organ culture of mouse TPTGs has not been reported previously. Therefore, we established the stability of the system with respect to PTH secretion. PTH secretion was maintained over a 2-week period, and the rate of PTH release consistently increased slightly during the cultures. As shown in Fig. 1, a 2-day treatment with $1 \alpha, 25(\mathrm{OH})_{2} \mathrm{D}_{3}$ reduced PTH secretion by over $90 \%$. The slow rate of suppression is consistent with a transcriptional repression and relatively long half-life of Pth mRNA (Ritter et al. 2008). Note that the reduction in $\mathrm{PTH}$ continued for $24 \mathrm{~h}$ after washout of the $1 \alpha, 25(\mathrm{OH})_{2} \mathrm{D}_{3}$. PTH release returned to basal levels over several days, confirming that the reduction in PTH was not attributable to cell death. These findings illustrate the utility of the TPTG organ model to study parathyroid gland function.

\section{The role of the VDR in the suppression of PTH by $1 \alpha, 25(\mathrm{OH})_{2} \mathrm{D}_{3}$ and prohormones}

The role of the VDR in the suppression of PTH by vitamin $\mathrm{D}$ compounds was investigated using

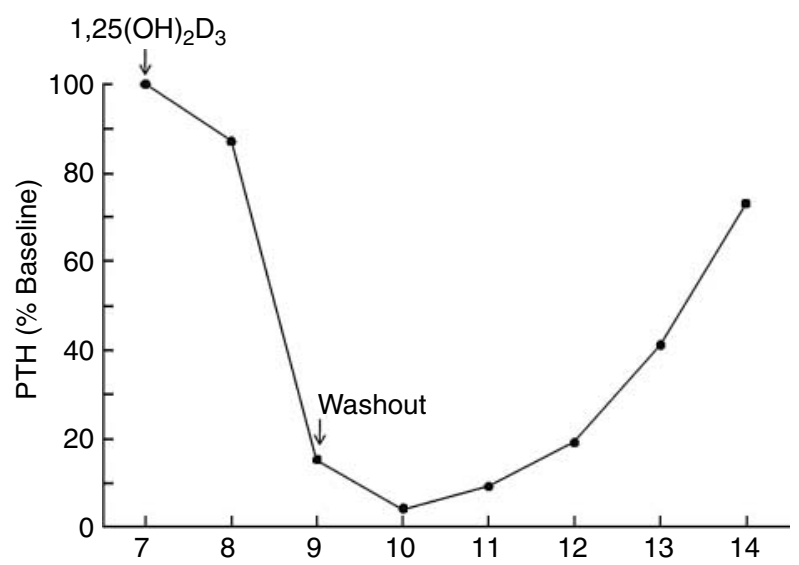

Figure 1 Suppression of $\mathrm{PTH}$ by $1 \alpha, 25(\mathrm{OH})_{2} \mathrm{D}_{3}$. A representative wild-type mouse thyroparathyroid complex, cultured in serum-free medium, was treated at days 7 and 8 of culture with $100 \mathrm{nM}$ $1 \alpha, 25(\mathrm{OH})_{2} \mathrm{D}_{3}$. Medium was collected daily for $\mathrm{PTH}$ measurements. 


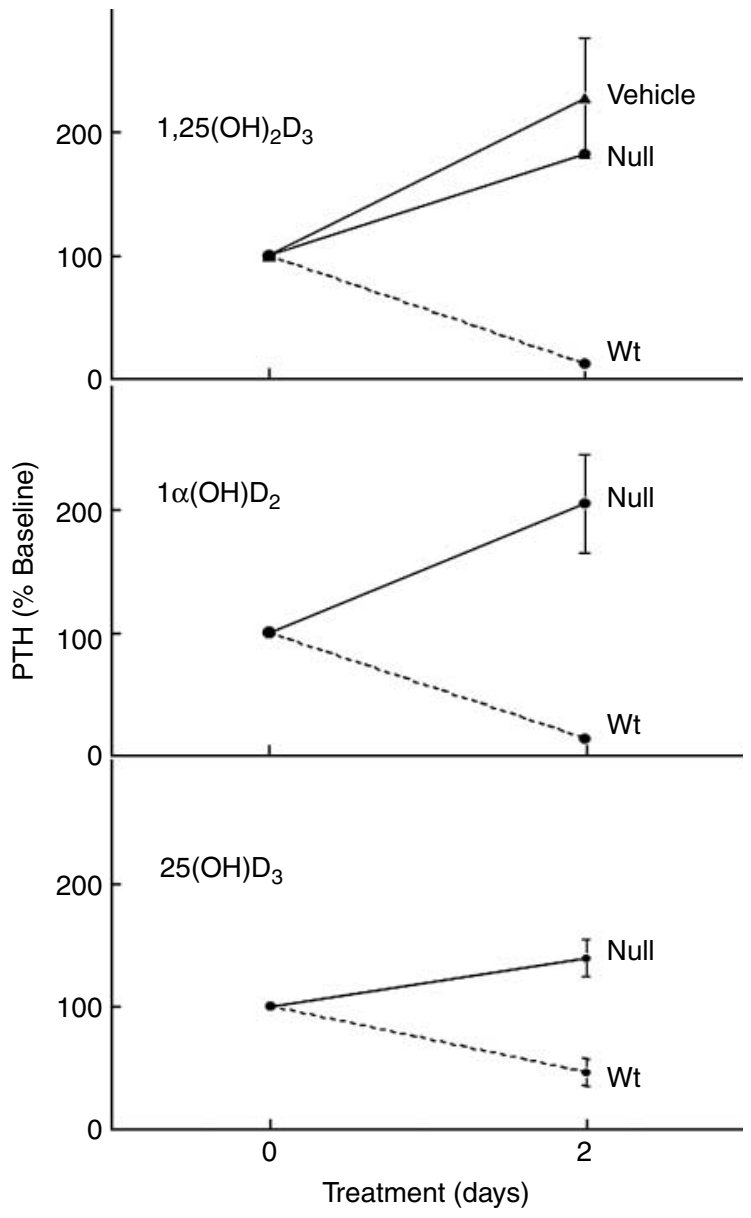

Figure 2 Effects of $1 \alpha, 25(\mathrm{OH})_{2} \mathrm{D}_{3}, 25(\mathrm{OH}) \mathrm{D}_{3}$, and $1 \alpha(\mathrm{OH}) \mathrm{D}_{2}$ on PTH secretion by thyroparathyroid complexes from wild-type and $V d r$-null mice. Thyroparathyroid complexes from $V d r$-null mice and wild-type littermates were treated with $100 \mathrm{nM} 1 \alpha, 25(\mathrm{OH})_{2} \mathrm{D}_{3}$, $25(\mathrm{OH}) \mathrm{D}_{3}$, and $1 \alpha(\mathrm{OH}) \mathrm{D}_{2}$ for 2 days, with daily measurement of PTH. Data are expressed as mean \pm s.E.M., $n=3-5$.

cultured TPTGs from wild-type and $V d r$-null mice. $1 \alpha, 25(\mathrm{OH})_{2} \mathrm{D}_{3}, 25(\mathrm{OH}) \mathrm{D}_{3}$, and $1 \alpha(\mathrm{OH}) \mathrm{D}_{2}$ were all active in wild-type cultures but were completely inactive in cultures from the $V d r$-null mice (Fig. 2).

\section{Discussion}

Transcriptional control of PTH expression by $1 \alpha, 25(\mathrm{OH})_{2} \mathrm{D}_{3}$ has been demonstrated in cell culture (Russell et al. 1986, Russell \& Sherwood 1987) and in vivo (Silver et al. 1986), but the exact mechanism remains controversial (Mackey et al. 1996, Koszewski et al. 1999, Murayama et al. 2004). None of the transcriptional mechanisms have been confirmed in parathyroid cells, and direct involvement of the VDR has not been demonstrated. In the current study, we developed a novel organ culture model for the study of parathyroid gland function ex vivo. For the first time, we provide proof of the requirement of the VDR for repression of PTH by $1 \alpha, 25(\mathrm{OH})_{2} \mathrm{D}_{3}$.

Previous studies from our group found that vitamin D prohormones can directly suppress PTH in bovine parathyroid cell culture. $1 \alpha(\mathrm{OH}) \mathrm{D}_{2}$, which has 600 times lower affinity for the VDR than $1 \alpha, 25(\mathrm{OH})_{2} \mathrm{D}_{3}$ (Okamura \& Zhu 1997), was shown to suppress PTH secretion and PTH mRNA in bovine parathyroid cultures, even when activation to $1 \alpha, 25(\mathrm{OH})_{2} \mathrm{D}_{2}$ or $1 \alpha, 24(\mathrm{OH})_{2} \mathrm{D}_{2}$ was blocked by the cytochrome $\mathrm{P} 450$ inhibitor ketoconazole (Brown et al. 2006). Similarly, $25(\mathrm{OH}) \mathrm{D}_{3}$, which also has 600 times lower affinity than $1 \alpha, 25(\mathrm{OH})_{2} \mathrm{D}_{3}$ for the VDR (Norman et al. 2001), suppressed PTH in cultured bovine parathyroid cells when its activation to $1 \alpha, 25(\mathrm{OH})_{2} \mathrm{D}_{3}$ was inhibited by clotrimazole (Ritter et al. 2006). The explanation for these surprising findings was unclear, but one possibility was that the control of PTH expression by $25(\mathrm{OH}) \mathrm{D}_{3}$ and $1 \alpha(\mathrm{OH}) \mathrm{D}_{2}$ is mediated by another receptor. This hypothesis was tested using cultured TPTGs from $V d r$ knockout and wild-type mice. The results revealed unequivocally that regulation of PTH by these two 'precursors' requires the VDR.

The mechanism for the direct effect of the two prohormones remains to be elucidated. It is possible that the equilibrium binding method used to measure VDR affinity may not accurately reflect the dynamic situation within the cell. For example, $25(\mathrm{OH}) \mathrm{D}_{3}$ and $1 \alpha(\mathrm{OH}) \mathrm{D}_{2}$ may dissociate from the VDR during the separation of bound and free ligand in the assay, causing an underestimation of the interaction that would occur in vivo or in cell culture where the concentrations of the compounds would be constant. Another possibility is that the two compounds, which are more hydrophobic than $1 \alpha, 25(\mathrm{OH})_{2} \mathrm{D}_{3}$, may be sequestered at high enough concentrations within the cells to overcome the weaker VDR affinity. This hypothesis is consistent with preliminary findings that cellular uptake of $1 \alpha(\mathrm{OH}) \mathrm{D}_{2}$ is much higher than that of $1 \alpha, 24(\mathrm{OH})_{2} \mathrm{D}_{2}$ (CS Ritter \& AJ Brown 2006, unpublished data). The explanation for the higher cellular and nuclear content of $1 \alpha(\mathrm{OH}) \mathrm{D}_{2}$ is unclear, but the intracellular vitamin D-binding proteins, HSC70 (Adams et al. 2004) and BAG1 (Chun et al. 2007), have been shown to play a role in cellular distribution of vitamin $\mathrm{D}$ compounds and may enhance the activities of the prohormones relative to $1 \alpha, 25(\mathrm{OH})_{2} \mathrm{D}_{3}$. Other explanations, such as differential recruitment of transcriptional co-regulators, cannot be excluded.

As illustrated by the current study, thyroparathyroid organ culture from transgenic mice provides a useful model for studying the effects of genetic modifications on parathyroid gland function ex vivo. In vivo approaches are limited in their interpretation because disruptions that affect PTH will be subject to feedback by calcium and vitamin $\mathrm{D}$, making it difficult to identify 
primary and secondary effects. Our findings demonstrate that PTH release is stable over several days and is regulated by vitamin $\mathrm{D}$ compounds. The potential utility of this model to study parathyroid hyperplasia is under investigation.

\section{Declaration of interest}

The authors declare that there is no conflict of interest that could be perceived as prejudicing the impartiality of the research reported.

\section{Funding}

This investigator-initiated study was sponsored by a grant from Genzyme Corporation.

\section{Acknowledgements}

We thank Drs Stephen Strugnell and Joyce Knutson for their invaluable discussions of the study.

\section{References}

Adams JS, Chen H, Chun R, Gacad MA, Encinas C, Ren S, Nguyen L, Wu S, Hewison M \& Barsony J 2004 Response element binding proteins and intracellular vitamin $\mathrm{D}$ binding proteins: novel regulators of vitamin D trafficking, action and metabolism. Journal of Steroid Biochemistry and Molecular Biology 89-90 461-465. (doi:10. 1016/j.jsbmb.2004.03.016)

Brown AJ, Ritter CS, Knutson JC \& Strugnell SA 2006 The vitamin D prodrugs lalpha $(\mathrm{OH}) \mathrm{D}_{2}$, lalpha $(\mathrm{OH}) \mathrm{D}_{3}$ and $\mathrm{BCI}-210$ suppress PTH secretion by bovine parathyroid cells. Nephrology, Dialysis, Transplantation 21 644-650. (doi:10.1093/ndt/gfil86)

Chun RF, Gacad M, Nguyen L, Hewison M \& Adams JS 2007 Cochaperone potentiation of vitamin $\mathrm{D}$ receptor-mediated transactivation: a role for Bcl2-associated athanogene-1 as an intracellularbinding protein for 1,25-dihydroxyvitamin $\mathrm{D}_{3}$. Journal of Molecular Endocrinology 39 81-89. (doi:10.1677/JME-07-0042)

Koszewski NJ, Ashok S \& Russell J 1999 Turning a negative into a positive: vitamin $\mathrm{D}$ receptor interactions with the avian parathyroid hormone response element. Molecular Endocrinology 13 455-465. (doi:10.1210/me.13.3.455)
Li YC, Pirro AE, Amling M, Delling G, Baron R, Bronson R \& Demay MB 1997 Targeted ablation of the vitamin D receptor: an animal model of vitamin D-dependent rickets type II with alopecia. PNAS 94 9831-9835. (doi:10.1073/pnas.94.18.9831)

Mackey SL, Heymont JL, Kronenberg HM \& Demay MB 1996 Vitamin D receptor binding to the negative human parathyroid hormone vitamin D response element does not require the retinoid $\mathrm{X}$ receptor. Molecular Endocrinology 10 298-305. (doi:10.1210/me.10.3.298)

Murayama A, Kim MS, Yanagisawa J, Takeyama K \& Kato S 2004 Transrepression by a liganded nuclear receptor via a bHLH activator through co-regulator switching. EMBO Journal 23 1598-1608. (doi:10.1038/sj.emboj.7600157)

Norman AW, Ishizuka S \& Okamura WH 2001 Ligands for the vitamin D endocrine system: different shapes function as agonists and antagonists for genomic and rapid response receptors or as a ligand for the plasma vitamin D binding protein. Journal of Steroid Biochemistry and Molecular Biology 76 49-59. (doi:10.1016/S09600760(00) 00145-X)

Okamura WH \& Zhu GD 1997 Chemistry and design: structural biology of vitamin D action. In Vitamin D, pp 939-971. Eds D Feldman, FH Glorieux \& JW Pike. San Diego: Academic Press.

Panda DK, Miao D, Bolivar I, Li J, Huo R, Hendy GN \& Goltzman D 2004 Inactivation of the 25-hydroxyvitamin D lalpha-hydroxylase and vitamin $\mathrm{D}$ receptor demonstrates independent and interdependent effects of calcium and vitamin $\mathrm{D}$ on skeletal and mineral homeostasis. Journal of Biological Chemistry 279 16754-16766. (doi:10.1074/jbc.M310271200)

Ritter CS, Armbrecht HJ, Slatopolsky E \& Brown AJ 2006 25-Hydroxyvitamin D(3) suppresses PTH synthesis and secretion by bovine parathyroid cells. Kidney International $70654-659$. (doi:10.1038/sj.ki.5000394)

Ritter CS, Pande S, Krits I, Slatopolsky E \& Brown AJ 2008 Destabilization of parathyroid hormone mRNA by extracellular $\mathrm{Ca}^{2+}$ and the calcimimetic R-568 in parathyroid cells: role of cytosolic Ca and requirement for gene transcription. Journal of Molecular Endocrinology 40 13-21. (doi:10.1677/JME-07-0085)

Russell J \& Sherwood LM 1987 The effects of 1,25-dihydroxyvitamin $D_{3}$ and high calcium on transcription of the pre-proparathyroid hormone gene are direct. Transactions of the Association of American Physicians 100 256-262.

Russell J, Lettieri D \& Sherwood LM 1986 Suppression by $1,25(\mathrm{OH})_{2} \mathrm{D}_{3}$ of transcription of the pre-proparathyroid hormone gene. Endocrinology 119 2864-2866. (doi:10.1210/endo-119-6-2864)

Silver J, Naveh-Many T, Mayer H, Schmelzer HJ \& Popovtzer MM 1986 Regulation by vitamin D metabolites of parathyroid hormone gene transcription in vivo in the rat. Journal of Clinical Investigation $\mathbf{7 8}$ 1296-1301. (doi:10.1172/JCI112714)

Received in final form 12 November 2010

Accepted 17 December 2010

Made available online as an Accepted Preprint 17 December 2010 